\title{
Production and Profitability of Maize as Influenced by Different Levels of Nitrogen, Phosphorus and Zinc in Central Plateau Zone of Maharashtra
}

\author{
A. K. Keteku ${ }^{1}$, W. N. Narkhede ${ }^{2}$ and G. S. Khazi ${ }^{3^{*}}$ \\ ${ }^{123}$ Dept. of Agronomy, ${ }^{2}$ AICRP on Integrated Farming System, College of Agriculture, Vasantrao Naik Marathwada Krishi \\ Vidyapeeth, Parbhani, Maharashtra (431 402), India
}

\section{Corresponding Author}

G. S. Khazi

e-mail: khazi.theagronomist@gmail.com

\author{
Article History \\ Manuscript No. AR1701 \\ Received in $28^{\text {th }}$ Sep, 2016 \\ Received in revised form $28^{\text {th }}$ Jan, 2017 \\ Accepted in final form $6^{\text {th }}$ Feb, 2017
}

\begin{abstract}
A field experiment was carried out on clayey soil at the experimental farm, AICRP on integrated farming systems, VNMKV, Parbhani during kharif 2014 to evaluate the effect of nitrogen, phosphorus and zinc on yield attributes, yield and economics of maize crop. The experiment was laid out in split plot design comprising two main plot factors ( $\mathrm{N}$ and $\mathrm{Zn}$ ) and $\mathrm{P}$ as Sub-plot factors. Nitrogen was applied at three levels (100, 125 and $150 \mathrm{~kg} \mathrm{ha}^{-1}$ ), Zinc was applied at two levels (25 and $35 \mathrm{~kg} \mathrm{ZnSO}_{4} \mathrm{~kg} \mathrm{ha}^{-1}$ ) and phosphorus was applied at three levels (50, 75 and $\left.100 \mathrm{~kg} \mathrm{ha}^{-1}\right)$. Application of nitrogen at $150 \mathrm{~kg}$ and $125 \mathrm{~kg} \mathrm{ha}^{-1}$ was found at par for maize grain yield and were significantly superior over $100 \mathrm{~kg} \mathrm{~N} \mathrm{ha}^{-1}$. The application of 25 and $35 \mathrm{~kg} \mathrm{ZnSO}_{4}$ ha $^{-1}$ did not affect maize grain yield significantly. Similarly, application of 100 and $75 \mathrm{~kg} \mathrm{P} \mathrm{ha}^{-1}$ were at par in respect to grain yield and was significantly superior over $50 \mathrm{~kg} \mathrm{P} \mathrm{ha}^{-1}$. Gross monetary returns, net monetary returns and $\mathrm{B}: \mathrm{C}$ ratio increased with increasing level of $\mathrm{N}, \mathrm{P}$ and $\mathrm{Z}$ except in $\mathrm{B}: \mathrm{C}$ ratio where $75 \mathrm{~kg} \mathrm{P}^{-1}$ recorded maximum value (2.83). A significant $\mathrm{N} \times \mathrm{P}$ interaction was observed in respect to no. grains $\operatorname{cob}^{-1}$ and grain weight plant ${ }^{-1}$. The interaction effect between nitrogen and zinc was also significant on maize spindle yield.
\end{abstract}

Keywords: Little millet, organic, inorganic, biofertilizers

\section{Introduction}

Maize is called as queen of cereal due to its great importance in human, animal diet and high yielding ability. It is the crop of the future as mentioned by the Father of Green Revolution, Renounced Nobel Laureate Dr. Norman E. Borlaug. Maize plays a vital role in ensuring food security as well as nutritional security through quality protein Manan et al. (2013). It has an important role in the industry as more than 35 products of daily use are derived from maize. It is raw material for a no. of products via. Starch, lactic acid, glucose, acetic acid, dextrose, sorbitol, dextrine, high fructose syrup, maltodextrine, germ oil, germ application in industries such as alcohol, textile, paper, pharmaceutical, organ chemical, cosmetics and edible oil. On an average, $1 \mathrm{t}$ maize gives $400 \mathrm{l}$. ethanol while $1 \mathrm{t}$ sugar beet/sugarcane gives only $100 \mathrm{I}$. Ethanol. In general, 15 thousand ha area gives 13400 I. ethanol (Kadam, 2008).

Maize is principally a rainy season crop and requires a minimum soil temperature of $13^{\circ} \mathrm{C}$ for germination and root development (optimum range $21^{\circ} \mathrm{C}-27^{\circ} \mathrm{C}$ ). It response well to warm conditions (optimum of $21^{\circ} \mathrm{C}-30^{\circ} \mathrm{C}$ ) as growth increases with temperature up to $30^{\circ} \mathrm{C}$. In Maharashtra, the area and production of maize is about $1.21 \mathrm{mha}$ and $3.98 \mathrm{mt}$ productions with the productivity of $2544 \mathrm{~kg} \mathrm{ha}^{-1}$ (Anonymous, 2014).

As maize is more exhausting in its demand for growth promoting factors, it is very crucial to determine the optimum rate of nitrogen fertilizer application as exceeding dosage may result in crop lodging, delayed silking, enhanced no. of barren ears, poor grain quality and subsequently, lower grain productivity. Furthermore, in Maharashtra, predominantly in Marathwada region, sorghum (most important staple food crop) is being replaced by maize in kharif season. Nitrogen, phosphorus and zinc have been reported as the third most important limiting nutrient elements in crop production. Zinc is the important micro nutrient for cereals particularly maize. Therefore, the knowledge of nitrogen, phosphorus and zinc, their dose, method and application rate must be properly evaluated for maize crop. In view of the above, these study was undertaken.

\section{Materials and Methods}

The field experiment was conducted at AICRP on integrated farming systems, VNMKV, Parbhani during kharif, 2014. The soil of the experimental field was clayey in texture, low in available $\mathrm{N}\left(186.42 \mathrm{~kg} \mathrm{ha}^{-1}\right)$, medium in available P (17.18 kg 
$\left.\mathrm{ha}^{-1}\right)$, and high in available $\mathrm{K}\left(519.18 \mathrm{~kg} \mathrm{ha}^{-1}\right)$ with $\mathrm{pH}$ 7.9. A split plot design with three replications for eighteen treatments combinations was followed. Treatments include combinations of various levels of nitrogen, phosphorus and zinc. The levels of nitrogen include 100, 125 and $150 \mathrm{~kg} \mathrm{ha}^{-1}$ and zinc levels are 25 and $35 \mathrm{~kg} \mathrm{ha}^{-1}$ in main plot and three phosphorus levels (50, 75 and $\left.100 \mathrm{~kg} \mathrm{ha}^{-1}\right)$ in sub-plots. Nitrogen was applied through neem coated urea- $46 \%$ as treatments ${ }^{-1}$ in two equal splits at sowing (basal) and knee height stage (top dress). The full dose of phosphorus and zinc were applied through single super phosphate (SSP-16\%) and Zinc sulphate $\left(\mathrm{ZnSO}_{4}-23 \%\right)$ as treatment ${ }^{-1}$ at the time of sowing respectively. A common dose of potassium was applied through muriate of potash at the rate of $75 \mathrm{~kg} \mathrm{ha}^{-1}$ to all treatment plots at sowing. Fertilizer application was done by peg method. Maize hybrid, RASI3022 was dibbled along a row spacing of $60 \times 30 \mathrm{~cm}^{2}$, with a seed rate of $18 \mathrm{~kg} \mathrm{ha}^{-1}$. The statistical analysis was done as suggested by Panse and Sukhatme (1967). Cost of cultivation, gross and net monetary returns and $\mathrm{B}: \mathrm{C}$ ratio was calculated on ha ${ }^{-1}$ basis using the prevailing market prices of input and output. The harvest index, net monetary returns and benefit cost ratio were worked out by using the following equations:

$H I(\%)=\frac{\text { Economic yield }}{\text { Biological yield }} \times 100$

NMR $=$ GMR-cost of cultivation

$\mathrm{B}: \mathrm{C}=\mathrm{GMR} /$ cost of cultivation

\section{Results and Discussion}

\subsection{Effect on yield attributes}

Variations in grain and biological yield can be determined from differences in yield attributes, as yield of maize is a function of yield attributing characters viz., no. of cobs plant ${ }^{-1}$, cob weight plant ${ }^{-1}$, husk weight plant ${ }^{-1}$, spindle weight plant ${ }^{-1}$, grain rows $\mathrm{cob}^{-1}$, number of grains $\mathrm{cob}^{-1}$, grain weight plant ${ }^{-1}$ and 1000 seeds weight.

The yield attributing characters (Table 1 and 2) stated above were influenced significantly by varying rate of nitrogen. There was a significant variation in yield contributing characters with increasing $\mathrm{N}$ rate. Application of $150 \mathrm{~kg} \mathrm{~N}^{-1}$ recorded highest values over $125 \mathrm{~kg}$ and $100 \mathrm{~kg} \mathrm{~N} \mathrm{ha}^{-1}$, though it was at par with $125 \mathrm{~kg} \mathrm{~N} \mathrm{ha}^{-1}$ in some cases. This may be attributed to the beneficial effects of higher levels of $\mathrm{N}$ on dry matter accumulation, ultimately reflected in increasing the yield attributing characters, the higher availability of source under the higher $\mathrm{N}$ rates created more sink than the lower $\mathrm{N}$ rates. These findings are in agreement with reports of Meena et al. (2011).

Yield attributes viz., cob weight plant ${ }^{-1}$, and grain weight plant ${ }^{-1}$ increased with application of $35 \mathrm{~kg} \mathrm{ZnSO}_{4}$ ha $^{-1}$ over $25 \mathrm{~kg} \mathrm{ZnSO}_{4} \mathrm{ha}^{-1}$. Zinc is involved in protein synthesis and biosynthesis of Indole 3-acetic acid (a growth hormone, involved in cell division and cell elongation), which may have caused an increase in plant height, no. of leaves, leaf area and dry matter accumulation, resulting in higher yield attributes. These findings are in agreement with Masood et al. (2011). Thousand seeds weight did not vary statistically
Table 1: No. of cob, cob weight, husk weight and spindle wt. plant $^{-1}(\mathrm{~g})$ as influenced by different treatments in maize

\begin{tabular}{|c|c|c|c|c|}
\hline \multirow[t]{2}{*}{ Treatments } & \multicolumn{4}{|c|}{ Yield attributes } \\
\hline & No. of cobs & $\begin{array}{l}\text { Cob } \\
\text { wt. }\end{array}$ & Husk wt. & $\begin{array}{c}\text { Spindle } \\
\text { wt. }\end{array}$ \\
\hline \multicolumn{5}{|c|}{$\mathrm{N}$ levels $\left(\mathrm{kg} \mathrm{ha}^{-1}\right)$-main plot } \\
\hline $\mathrm{N}_{1}: 100$ & 1.20 & 186.62 & 11.7 & 15.8 \\
\hline $\mathrm{N}_{2}: 125$ & 1.64 & 224.83 & 14.3 & 20.5 \\
\hline $\mathrm{N}_{3}: 150$ & 1.72 & 238.44 & 15.5 & 24.8 \\
\hline SEm \pm & 0.06 & 3.53 & 0.41 & 0.63 \\
\hline $\mathrm{CD}^{*}$ & 0.19 & 11.1 & 1.29 & 1.97 \\
\hline \multicolumn{5}{|c|}{$\mathrm{Z}$ levels $\left(\mathrm{kg} \mathrm{ha}^{-1}\right)$-main plot } \\
\hline$Z_{1}: 25$ & 1.47 & 210.60 & 13.4 & 20.3 \\
\hline$Z_{2}: 35$ & 1.49 & 223.03 & 14.2 & 25.4 \\
\hline SEm \pm & 0.05 & 2.88 & 0.34 & 0.51 \\
\hline$C D^{*}$ & NS & 9.05 & NS & NS \\
\hline \multicolumn{5}{|c|}{ P levels (kg ha-1)-sub plot } \\
\hline$P_{1}: 50$ & 1.40 & 206.62 & 13.2 & 19.0 \\
\hline$P_{2}: 75$ & 1.48 & 218.99 & 13.7 & 20.9 \\
\hline$P_{3}: 100$ & 1.56 & 224.82 & 14.5 & 21.2 \\
\hline SEm \pm & 0.04 & 2.22 & 0.25 & 0.54 \\
\hline $\mathrm{CD}^{*}$ & 0.12 & 6.47 & 0.73 & 1.57 \\
\hline \multicolumn{5}{|l|}{ Interaction } \\
\hline \multicolumn{5}{|l|}{$N \times Z$} \\
\hline SEm \pm & 0.08 & 4.99 & 0.58 & 0.88 \\
\hline$C D^{*}$ & NS & NS & NS & NS \\
\hline \multicolumn{5}{|l|}{$\mathrm{N} \times \mathrm{P}$} \\
\hline SEm \pm & 0.07 & 3.84 & 0.44 & 0.93 \\
\hline $\mathrm{CD}^{*}$ & NS & NS & NS & NS \\
\hline \multicolumn{5}{|l|}{$Z \times P$} \\
\hline SEm \pm & 0.06 & 3.14 & 0.36 & 0.76 \\
\hline$C D^{*}$ & NS & NS & NS & NS \\
\hline \multicolumn{5}{|l|}{$\mathrm{N} \times \mathrm{Z} \times \mathrm{P}$} \\
\hline SEm \pm & 0.10 & 5.44 & 0.62 & 1.32 \\
\hline$C D^{*}$ & NS & NS & NS & NS \\
\hline $\begin{array}{l}\text { General } \\
\text { mean }\end{array}$ & 1.50 & 216.74 & 13.8 & 20.4 \\
\hline
\end{tabular}

$\mathrm{CD}^{*}: \mathrm{CD}(p=0.05)$

with increasing $\mathrm{Z}$ level, indicating that $25 \mathrm{~kg} \mathrm{ZnSO}_{4}$ ha $^{-1}$ was the optimum range. Similar report was observed by Olusegun et al. (2014).

Perusal of the data revealed that different levels of phosphorus had significant effect on yield attributes of maize. 
Table 2: Grain row $\mathrm{cob}^{-1}$, no. of grains $\mathrm{cob}^{-1}$, grain weight plant $^{-1}$ and 1000 seeds weight as influenced by different treatments in maize

\begin{tabular}{|c|c|c|c|c|}
\hline \multirow{2}{*}{$\begin{array}{l}\text { Treat- } \\
\text { ments }\end{array}$} & \multicolumn{4}{|c|}{ Yield attributes } \\
\hline & $\begin{array}{c}\text { Grain } \\
\text { row } \text { cob }^{-1}\end{array}$ & $\begin{array}{c}\text { No. of } \\
\text { grains cob } \text { cob }^{-1}\end{array}$ & $\begin{array}{l}\text { Grain wt. } \\
\text { plant }^{-1}(\mathrm{~g})\end{array}$ & $\begin{array}{c}1000 \text { seeds } \\
\text { wt. (g) }\end{array}$ \\
\hline \multicolumn{5}{|c|}{$\mathrm{N}$ levels $\left(\mathrm{kg} \mathrm{ha}^{-1}\right)$-main plot } \\
\hline $\mathrm{N}_{1}: 100$ & 12.21 & 424.68 & 138.27 & 299.81 \\
\hline $\mathrm{N}_{2}: 125$ & 13.70 & 475.11 & 171.04 & 301.97 \\
\hline$N_{3}: 150$ & 15.39 & 536.88 & 192.03 & 302.27 \\
\hline SEm \pm & 0.16 & 4.41 & 4.94 & 0.13 \\
\hline$C D^{*}$ & 0.51 & 13.9 & 15.5 & 0.42 \\
\hline \multicolumn{5}{|c|}{$\mathrm{Z}$ levels $\left(\mathrm{kg} \mathrm{ha}^{-1}\right)$-main plot } \\
\hline$Z_{1}: 25$ & 13.65 & 474.68 & 166.03 & 300.64 \\
\hline$Z_{2}: 35$ & 13.88 & 483.09 & 180.86 & 300.75 \\
\hline SEm \pm & 0.13 & 6.24 & 4.04 & 0.10 \\
\hline$C D^{*}$ & NS & NS & 12.7 & NS \\
\hline \multicolumn{5}{|c|}{ P levels (kg ha-1)-sub plot } \\
\hline$P_{1}: 50$ & 13.29 & 451.43 & 153.36 & 300.23 \\
\hline$P_{2}: 75$ & 13.93 & 481.76 & 173.06 & 300.98 \\
\hline$P_{3}: 100$ & 14.10 & 503.47 & 187.29 & 301.18 \\
\hline SEm \pm & 0.19 & 4.60 & 4.93 & 0.07 \\
\hline$C D^{*}$ & 0.54 & 13.4 & 14.3 & 0.22 \\
\hline \multicolumn{5}{|c|}{ Interaction } \\
\hline \multicolumn{5}{|l|}{$N \times Z$} \\
\hline SEm \pm & 0.23 & 6.24 & 6.99 & 0.21 \\
\hline$C D^{*}$ & NS & NS & NS & NS \\
\hline \multicolumn{5}{|l|}{$N \times P$} \\
\hline SEm \pm & 0.32 & 7.97 & 8.53 & 0.13 \\
\hline$C D^{*}$ & NS & 23.2 & 24.8 & NS \\
\hline \multicolumn{5}{|l|}{$\overline{Z \times P}$} \\
\hline SEm \pm & 0.26 & 6.51 & 6.96 & 0.10 \\
\hline $\mathrm{CD}^{*}$ & NS & NS & NS & NS \\
\hline \multicolumn{5}{|l|}{$\mathrm{N} \times \mathrm{Z} \times \mathrm{P}$} \\
\hline SEm \pm & 0.45 & 11.27 & 12.06 & 0.17 \\
\hline $\mathrm{CD}^{*}$ & NS & NS & NS & NS \\
\hline $\begin{array}{l}\text { General } \\
\text { mean }\end{array}$ & 13.77 & 478.89 & 170.24 & 300.97 \\
\hline
\end{tabular}

$C D^{*}: \mathrm{CD}(p=0.05)$

Phosphorus application at $100 \mathrm{~kg} \mathrm{ha}^{-1}$ recorded higher values in husk weight plant ${ }^{-1}$, grain no. cob $^{-1}$ and grain weight plant ${ }^{-1}$ over $75 \mathrm{~kg} \mathrm{ha}^{-1}$. A rise in $\mathrm{P}$ level increased yield attributing characters as observed. The possible reason could be that higher $\mathrm{P}$ level might have resulted in greater assimilates partitioning to the cobs which increase the no. of rows and grains no. $\mathrm{cob}^{-1}$ compared with that obtained with lower $\mathrm{P}$ level. Amanullah and Muhammad Zakirullah (2010) also report that yield attribute of maize increased with increasing levels of $\mathrm{P}$. Phosphorus being responsible for good root growth directly affected the thousand grain weight because $P$ rate at $50 \mathrm{~kg} \mathrm{ha}^{-1}$ resulted in the least thousand grain weight. The highest thousand grain weight of $301.18 \mathrm{~g}$ was obtained from $\mathrm{P}$ rate at $100 \mathrm{~kg} \mathrm{ha}^{-1}$ but was statistically at par with $75 \mathrm{~kg} \mathrm{P}$ $\mathrm{ha}^{-1}$. Highest grain weight with higher $\mathrm{P}$ level probably may be due to the higher $\mathrm{P}$ translocation into the fruiting areas which resulted in highest grain weight (Sushila Sepat and Rai, 2013).

\subsection{Effect on yield}

A significant difference in maize grain yield, husk yield, spindle yield and biological yield $\mathrm{ha}^{-1}$ were observed due to different $\mathrm{N}$ levels (Table 3). Application of $125 \mathrm{~kg} \mathrm{~N}^{-1}$ being on par with $150 \mathrm{~kg} \mathrm{~N} \mathrm{ha}^{-1}$ significantly improved grain and stover yield over $100 \mathrm{~kg} \mathrm{~N} \mathrm{ha}^{-1}$. The nitrogen application at $125 \mathrm{~kg}$ and $150 \mathrm{~kg} \mathrm{ha}^{-1}$ recorded (6705.8, 6428.4 and 7161, 6811.2 $\left.\mathrm{kg} \mathrm{ha}^{-1}\right)$ grain and stover yield respectively. Maximum husk, spindle and biological yield of (1378.2, 1642.6 and $13866.8 \mathrm{~kg}$ $\mathrm{ha}^{-1}$ ) were obtained by $\mathrm{N}$ application at $150 \mathrm{~kg} \mathrm{ha}^{-1}$ and were significantly superior over $125 \mathrm{~kg}$ and $100 \mathrm{~kg} \mathrm{ha}^{-1}$.

The increment in grain and biological yield with a rise in $\mathrm{N}$ level might be attributed to the optimum utilization of solar light, higher assimilates production due to higher growth character and it conversion to starches resulted in higher yield attributes, biomass and seed yield. Lower $\mathrm{N}$ fertilization decreased the grain and stover yield because it affects the no. of endospermatic cell and starch granules in the early post flowering period and also causes the reduction of source assimilation during grain filling period. These results are corroborated with Manan et al. (2013). Harvest index was highest at $150 \mathrm{~kg} \mathrm{~N} \mathrm{ha}^{-1}$ (48.4\%). It was significantly higher with application of $255 \mathrm{~kg} \mathrm{~N} \mathrm{ha}^{-1}$ over $75 \mathrm{~kg}$ and $150 \mathrm{~kg} \mathrm{~N} \mathrm{ha}^{-1}$ as reported by Olusegun et al. (2014).

Maize grain yield did not differ significantly with different zinc fertility levels. The zinc application @ $35 \mathrm{~kg} \mathrm{ZnSO}_{4} \mathrm{ha}^{-1}$ recorded a grain yield of $\left(6105.6 \mathrm{~kg} \mathrm{ha}^{-1}\right)$ and was at par with (5652.2 $\mathrm{kg} \mathrm{ha}^{-1}$ ) of $25 \mathrm{~kg} \mathrm{ZnSO}_{4} \mathrm{ha}^{-1}$. Increasing the amount of $\mathrm{Zn}$ applied from (10 to $40 \mathrm{~kg} \mathrm{ha}^{-1}$ ) did not affect grain yield statistically (Olusegun and Chirwa, 2014). However, stover yield and biological yield of maize were significantly superior with $35 \mathrm{~kg} \mathrm{ZnSO}_{4} \mathrm{ha}^{-1}$. The highest value of harvest index i.e. $46.7 \%$ was noted with $35 \mathrm{~kg} \mathrm{ZnSO}_{4} \mathrm{ha}^{-1}$. The result of this research confirms the previous works of Nsanzabaganwa et al. (2014).

Phosphorus levels had significant effect on grain, stover and biological yield of maize. Phosphorus application at 100 and 75 $\mathrm{kg} \mathrm{ha}^{-1}$ recorded at par higher grain yield of $6126 \mathrm{~kg}$ and 6003.2 $\mathrm{kg} \mathrm{ha}^{-1}$ respectively and were significantly superior over $50 \mathrm{~kg}$ $\mathrm{ha}^{-1}\left(5716.6 \mathrm{~kg} \mathrm{ha}^{-1}\right)$. Further increase in phosphorus from 75 to $100 \mathrm{~kg} \mathrm{ha}^{-1}$ though increased the grain yield but failed to register statistical significance. In case of stover and biological 
Table 3: Grain yield, husk yield, spindle yield, stover yield, biological yield $\left(\mathrm{kg} \mathrm{ha}^{-1}\right)$ and harvest index (\%) as influenced by different treatments in maize



Chaudhary et al. (2012) observed that increasing phosphorus level enhance maize yield.

\subsection{Effect on economic studies}

The effect of nitrogen application on GMR and NMR in maize was found significant with different nitrogen levels (Table 4).

Table 4: Gross and net monetary returns, cost of cultivation $\left(\mathrm{ha}^{-1}\right)$ and Benefit: Cost ratio of maize as influenced by different treatments

GMR: Gross monetary returns; NMR: Net monetary returns; 
increase in $\mathrm{N}$ level which was highest $\left(55.1 \times 10^{3} ₹ \mathrm{ha}^{-1}\right.$ and 2.95) with $150 \mathrm{~kg} \mathrm{~N} \mathrm{ha}^{-1}$. Manan et al. (2013) also recorded maximum $\mathrm{B}: \mathrm{C}$ ratio with increasing levels of nitrogen up to $220 \mathrm{~kg} \mathrm{ha}^{-1}$.

GMR and NMR were not influenced significantly by different $\mathrm{Zn}$ levels. However, the zinc application rate at $35 \mathrm{~kg} \mathrm{ZnSO}_{4} \mathrm{ha}^{-1}$ recorded higher GMR, NMR and B:C ratio of $\left(78.7 \times 10^{3}\right.$ ₹ ha-1, $50.3 \times 10^{3} ₹$ ha $^{-1}$ and 2.89 ) respectively. Effect of Phosphorus on GMR and NMR in maize was significant with all $P$ rates. Statistically, beneficial response was only up to $75 \mathrm{~kg} \mathrm{P} \mathrm{ha}^{-1}$. The phosphorus application at $75 \mathrm{~kg} \mathrm{ha}^{-1}$ registered highest $\mathrm{B}: \mathrm{C}$ ratio of (2.83) over $100 \mathrm{~kg}$ and $50 \mathrm{~kg} \mathrm{Pha}^{-1}$. It might be due to the beneficial effect of $\mathrm{P}$ on improving growth characters, yield attributes, grain yield and stover yield of maize. Singh et al. (2011) observed similar kind of results. Interaction effects on GMR and NMR due to N, P and $\mathrm{Zn}$ levels were not evident.

\subsection{Interaction effect}

A significant $\mathrm{N} \times \mathrm{P}$ interaction (Table 5 and 6 ) was observed in respect to no. grains $\mathrm{cob}^{-1}$ and grain weight plant ${ }^{-1}$. This may account for the higher yield produced by increasing levels of $\mathrm{N}$ and $\mathrm{P}$. These results are in agreement with Nsanzabaganwa et al. (2014) who observed a significant $N \times P$ interaction. The interaction effect between nitrogen and zinc was also significant on maize spindle yield. The highest maize spindle yield was recorded with $150 \mathrm{~kg} \mathrm{~N}^{-1}\left(1573.8 \mathrm{~kg} \mathrm{ha}^{-1}\right)$ and $35 \mathrm{~kg} \mathrm{ZnSO}_{4}\left(1711.4 \mathrm{~kg} \mathrm{ha}^{-1}\right)$. The least yield was registered with $100 \mathrm{~kg} \mathrm{~N} \mathrm{ha}^{-1}\left(1024.6 \mathrm{~kg} \mathrm{ha}^{-1}\right)$ and among zinc fertility levels with $25 \mathrm{~kg} \mathrm{ZnSO}_{4}\left(1159.9 \mathrm{~kg} \mathrm{ha}^{-1}\right)$. Owla et al. (2015) corroborate my results of the present study with respect to

Table 5: No. of grains $\operatorname{cob}^{-1}(\mathrm{~g})$ and grain weight plant ${ }^{-1}(\mathrm{~g})$ as influenced by $\mathrm{N} \times \mathrm{P}$ interaction in maize

\begin{tabular}{lccccccc}
\hline Treatment & \multicolumn{3}{c}{ No. of grains cob c $^{-1}$} & & \multicolumn{3}{c}{ Grain weight plant } \\
\cline { 2 - 4 } \cline { 7 - 8 } & $\mathrm{P}_{1}$ & $\mathrm{P}_{2}$ & $\mathrm{P}_{3}$ & & $\mathrm{P}_{1}$ & $\mathrm{P}_{2}$ & $\mathrm{P}_{3}$ \\
\hline $\mathrm{N}_{1}$ & 409.21 & 425.25 & 439.57 & & 129.3 & 134.8 & 151.5 \\
$\mathrm{~N}_{2}$ & 428.79 & 486.38 & 510.15 & & 145.2 & 168.6 & 199.3 \\
$\mathrm{~N}_{3}$ & 516.29 & 533.65 & 560.70 & & 186.5 & 215.9 & 219.2 \\
$\mathrm{SEm} \pm$ & & 7.97 & & & 8.1 & \\
$\mathrm{CD}$ & & 23.2 & & & 24.2 & \\
$(p=0.05)$ & & & & & & \\
\hline
\end{tabular}

Table 6: Spindle yield ha-1 as influenced by $\mathrm{N} \times \mathrm{Z}$ interaction in maize

\begin{tabular}{lcc}
\hline \multirow{2}{*}{ Treatment } & \multicolumn{2}{c}{ No. of grains cob ${ }^{-1}$} \\
\cline { 2 - 3 } & $\mathrm{Z}_{1}$ & $\mathrm{Z}_{2}$ \\
\hline $\mathrm{N}_{1}$ & 1024.6 & 1159.9 \\
$\mathrm{~N}_{2}$ & 1393.1 & 1515.3 \\
$\mathrm{~N}_{3}$ & 1573.8 & 1711.4 \\
$\mathrm{SEm} \pm$ & & 40.2 \\
$\mathrm{CD}(p=0.05)$ & & 126.5 \\
\hline
\end{tabular}

significant fertility levels interaction.

\section{Conclusion}

Application of nitrogen @ $150 \mathrm{~kg}$ and $125 \mathrm{~kg} \mathrm{ha}^{-1}$ being at par were significantly superior over $100 \mathrm{~kg} \mathrm{~N} \mathrm{ha}^{-1}$ to influence the maize grain yield. Similarly, phophorous @ 100 and 75 kg $\mathrm{ha}^{-1}$ being at par were were significantly superior over $50 \mathrm{~kg}$ $\mathrm{ha}^{-1}$. The application of 25 and $35 \mathrm{~kg} \mathrm{ZnSO}_{4} \mathrm{ha}^{-1}$ did not affect maize grain yield significantly. Gross monetary returns, net monetary returns and $\mathrm{B}: \mathrm{C}$ ratio increased with increasing level of $\mathrm{N}, \mathrm{P}$ and $\mathrm{Z}$ except in $\mathrm{B}: \mathrm{C}$ ratio where $75 \mathrm{~kg} \mathrm{P} \mathrm{ha}^{-1}$ recorded maximum value (2.83).

\section{References}

Anonymous, 2014. Agricultural statistics at a glance. Govt. of India, M/o Agriculture, Dept. of Agriculture and cooperation, D/o Economics and statistics.

Bhanu, B.P., Sah, S.K., Amgain, L.P., Ojha, B.R., 2005. Response of promising Maize cultivar to different nitrogen levels in winter. Maize Agronomy, Proceedings of the Tenth Asian Regional Maize Workshop. Section V, 479-483.

Chaudhary, M., Verma, A., Singh, H., 2012. Productivity and economics of maize (Zea mays L.) as influenced by phosphorus management in Southern Rajasthan. Annals of Agricultural Research, New Series 33(1\&2), 88-90.

Jat, R.A., Balyan, J.S., 2004. Effect of integrated nitrogen management on dry matter, yield attributes, yield and total $\mathrm{N}$ uptake. Annals of Agricultural Research, New Series 25(1), 153-154.

Kadam, A.L., 2008. Production of sweet corn. Maharashtra Journal of Agricultural Universities 4(3) 41-45.

Mahala, H.L., Shekhawat, M.S., 2001. Effect of source and levels of phosphorus and FYM on yield attributes, yield and nutrient uptake of maize (Zea mays L.) Annals of Agricultural Science, New Series 25(4), 571-576.

Manan, J., Singh, D., Manhas, S.S., 2013. Winter maize as affected by preceding rainy-season crops, farmyard manure and nitrogen levels. Indian Journal of Agronomy 58(4), 539-542.

Masood, T., Gul, R., Munsif, F., Jalal, F., Hussain, Z., Noreen, N., Khan, H., Nasiruddin and Khan, H., 2011. Effect of different phosphorus levels on the yield and yield components of maize. Sarhad Journal of Agriculture. 27(2), 167-170.

Meena, K.N., Kumar, A., Rana, D.S., Meena, M.C., 2011. Productivity and nutrient uptake of maize (Zea mays)wheat (Triticum aestivum) cropping system under different bio-sources and nitrogen levels. Indian Journal of Agronomy 56(3), 182-188.

Nsanzabaganwa, E.T., Das, T.K., Rana, D.S., Kumar, S.N., 2014. Nitrogen and phoephrous effects on winter maize in an irrigated agroecosystem in western Indo-Gangetic plains 
of India. Maydica electronic Publication 59, 152-160.

Olusegun, A., 2014. Soil and foliar application of zinc to maize and wheat grown on a Zambian Alfisol.. African Journal of Agricultural Research 9(11), 963-970.

Owla, M.L., Nepaaia, V., Chouhan, G.S., Singh, D., 2015. Effect of fertility levels. Nutrient sources and weed control on weed dynamics and yield of quality protein maize and relative nitrogen and phosphorus uptake. Indian Journal of Agronomy 60(2), 267-272.

Panse, V.G., Sukhatme, P.V., 1967. Statistical methods for Agricultural workers, ICAR, New Delhi.

Rawool, H.V., 2004. Effect of integrated nutrient management on yield and nutrient balance in maize (Zea mays L.). Indian Journal of Agricultural Science 46(4), 698-701.

Sharma, S.K., Swami, B.N., Singh, R.K., 1992. Relative response of maize (Zea mays L.) varieties to zinc. Indian Journal of Agronomy 37(2), 361-362.
Singh, M.K., Singh, R.N., Singh, V.K., 2011. Effect of organic and inorganic sources of nutrients on growth, yield, quality and nutrient uptake by baby corn (Zea mays).. Annals of Agricultural Research, New Series 32(3\&4), 93-99.

Srikanth, M., Md. Amanullah, M., Muthukrishnan, P., 2009. Influence of plant density and fertilizer on yield attributes yield and grain quality of hybrid maize. Madras Agricultural Journal 96(16), 139-143.

Sepat, S., Rai, R.K., 2013. Effect of phosphorus levels and sources on productivity nutrient uptake and soil fertility of maize (Zea mays)-wheat (Triticum aestivum) cropping system. Indian Journal of Agronomy 58(3), 292-297.

Tyagi, R.C., Singh, D., Hooda, I.S., 1998. Effect of plant population, irrigation and nitrogen on yield and its attributes of spring maize (Zea mays). Indian Journal of Agronomy 43(4), 672-676. 